\title{
KOMPARASI KINERJA APLIKASI KOMPUTER AKUNTANSI MYOB V.17 DAN ACCURATE V.4 PADA PROSES PENYELESAIAN TRANSAKSI PEMBELIAN DAN PENJUALAN
}

\author{
Mardiana Andarwati ${ }^{1)}$, Theresia Pradiani ${ }^{2)}$ \\ ${ }^{1)}$ Fakultas Teknologi Informasi Universitas Merdeka Malang \\ ${ }^{2)}$ Fakultas Ilmu Komputer Universitas Putera Batam
}

\begin{abstract}
Abstrak
Studi komparasi antara Myob dan Accurate untuk membandingkan perangkat lunak buatan lokal (dalam negeri) dan luar negeri. Myob merupakan perangkat lunak buatan Australia. Sedangkan Accurate merupakan produk buatan lokal (dalam negeri) yang secara umum lebih dapat memenuhi permintaan pasar di Indonesia. Hasil komparasi menunjukkan bahwa Accurate v. 4 untuk proses IPO pembelian tunai unggul \pm 1 menit. Sedangkan untuk proses IPO pembelian down payment dan untuk proses IPO pembelian kredit tidak menunjukkan perbedaan yang signifikan. Dan dalam penyelesaian langkah proses penjualan, sekali lagi Accurate v.4 menunjukkan keunggulan \pm 35 detik.
\end{abstract}

Kata kunci :komparasi, Myob, Accurate

\section{LATAR BELAKANG}

Saat ini banyak sekali program aplikasi komputer di bidang akuntansi yang sudah jadi dan siap untuk dipakai, baik produk buatan dalam negeri ataupun luar negeri. Program aplikasi akuntansi merupakan aplikasi yang dibangun secara otomatis untuk pembukuan yang lebih mudah menghasilkan laporan keuangan secara lebih lengkap, cepat, dan akurat. Program aplikasi akuntansi yang siap pakai ini biasanya dipergunakan bagi UKM (Usaha Kecil Menengah) yang dibuat secara terpadu (integrated). Produk ini menawarkan berbagai macam fitur untuk memantau kinerja perusahaan. Namun banyaknya produk perangkat lunak akuntansi di pasaran justru membingungkan, karena fitur tiap produk tersebut hampir sama, salah satunya MYOB dan Accurate.

Berdasarkan uraian di atas, penulis melakukan komparasi antara Myob dan Accurate untuk membandingkan perangkat lunak buatan lokal (dalam negeri) dan luar negeri. Dengan harapan user akan memperoleh gambaran kecocokan software akuntansi yang tersedia apabila akan diterapkan dan diimplementasikan untuk membantu pengelolaan bisnis. Myob merupakan software buatan luar negeri yaitu berasal dari Australia. Sedangkan Accurate merupakan produk buatan lokal (dalam negeri) yang secara umum lebih dapat memenuhi permintaan pasar di indonesia. Pemakaian perangkat lunak dipilih sesuai dengan visi pengguna yang bersifat masa depan untuk kemudian dijabarkan strateginya sesuai dengan visi pengguna. Disamping itu pemilihan perangkat lunak juga didasarkan pada pembenahan sistem dan pengembangan sumber daya manusianya. Dengan adanya penelitian ini maka akan didapat suatu output yang bisa menjadi acuan bagi para pengguna atau pemakai atau user perangkat lunak aplikasi akuntansi dalam mengaplikasikan Myob dan Accurate sesuai dengan kebutuhan pasar.

\section{METODOLOGI PENELITIAN}

Penelitian ini dilakukan dengan melakukan kajian teoritik untuk mengetahui gambaran umum yang signifikan pada Myob v.17 dan Accurate 
v.4. Dan melakukan perhitungan waktu penyelesaian proses pencatatan transaksi pembelian kepada supplier dan penjualan kepada customer pada perusahaan retail, dalam hal ini adalah mini market. Adapun secara spesifikasi, yang diuji antara lain

a. Komparasi gambaran umum secara signifikan fitur dari Myob dan Accurate

b. Uji kecepatan waktu dalam penyelesaian proses pembelian (pembelian tunai, pembelian dengan uang muka/down payment, pembelian kredit) dengan menggunakan Myob dan Accurate

c. Uji kecepatan waktu dalam penyelesaian proses penjualan (penjualan tunai, penjualan dengan uang muka/down payment, penjualan kredit) dengan menggunakan Myob dan Accurate

Berikut diagram alur penelitian untuk bisa mengetahui arah dan hasil yang diharapkan.

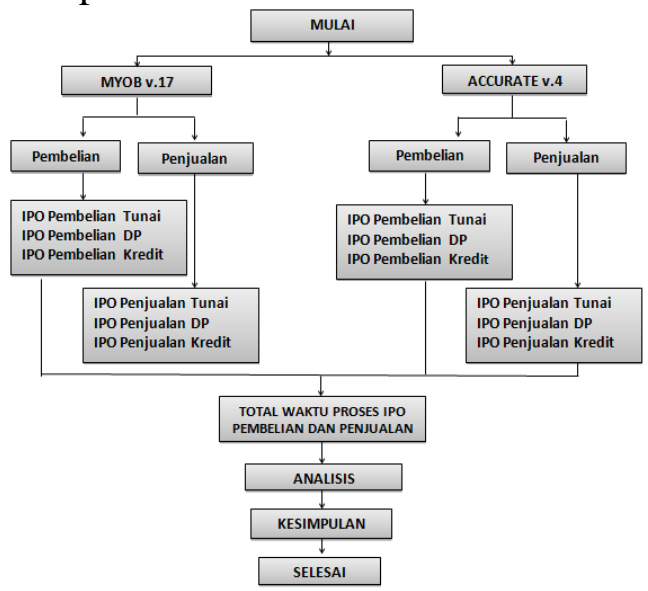

Gambar 1. Diagram Alur Penelitian

\section{HASIL PENELITIAN}

3.1. Gambaran Umum Myob v.17 dan Accurate v.4 Berdasarkan Studi Literatur

\section{Tampilan awal}

Perbedaan tampilan awal (starting display) antara Myob v.17 dan Accurate v.4 adalah pada saat membuka display Myob v.17 mempunyai tampilan yang terlihat formal dengan lima icon dan keterangan tentang icon tertera di sebelah kanan icon. Myob lebih menekankan ke arah tampilan default sebuah software bisnis.

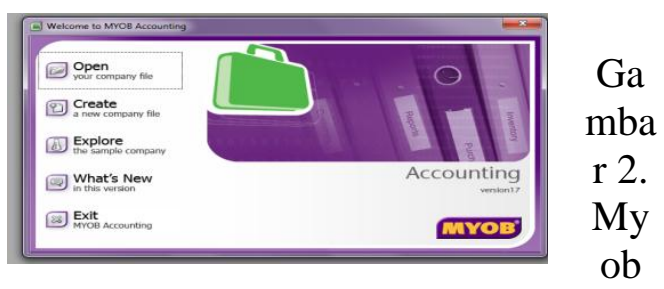

Starting Display

Pada saat pertama kali membuka Accurate v.4 akan terlihat display yang memiliki enam gambar icon di mana akan muncul keterangan tentang icon tersebut apabila cursor diarahkan di atas icon. Accurate menampilkan display atau tampilan yang lebih modern atau tampilan yang berbeda dari software akuntansi lain.

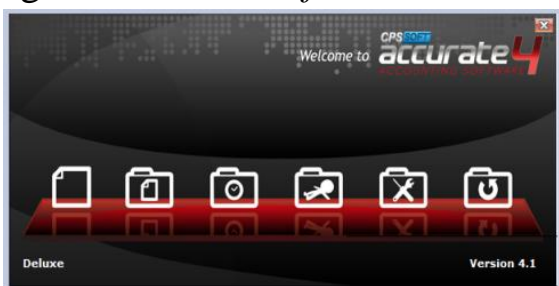

Gambar 3. Accurate Starting Display

\section{Setup Database}

Dalam hal pengoperasiannya, Myob menampilkan fitur yang mudah dipahami. Operator tinggal mengikuti alur proses yang disediakan dalam software Myob. Dalam men-setup di awal ketika hendak menyesuaikan dengan proses bisnis perusahaan memerlukan kejelian karena Myob telah menyediakan bentuk proses baku sesuai dengan pilihan ketika mensetup. Karena database Myob merupakan database yang dikunci, artinya pengguna tidak dapat melakukan modifikasi laporan, modifikasi field di Myob sehingga customization sulit untuk dipenuhi (tarymarthe). Sehingga apabila salah menentukan proses bisnis saat setup maka proses bisnis akan menjadi kurang relevan. Untuk proses bisnis UKM di Indonesia, mungkin software Myob kurang pas mengingat software ini dibangun atas memperhatikan kondisi bisnis di negara asalnya. Sedangkan untuk Accurate sangat mudah dan sangat aplikatif bagi proses bisnis UKM di Indonesia dan dalam 
penggunaan software ini juga sangat mudah diikuti tanpa memerlukan pengetahuan akuntansi sebelumnya. Dalam proses set up dibagi manjadi dua yaitu set up database dengan persiapan standart dan persiapan mahir.

Database untuk Myob merupakan database yang dikunci dalam arti pengguna tidak dapat melakukan modifikasi laporan, modifikasi field di Myob sehingga customization apabila diperlukan relatif sulit dipenuhi oleh Myob. Sedangkan database Accurate merupakan database server firebird, database SQL dari kelas Client/server. Sehingga Accurate mampu melayani sampai ratusan user sekaligus tanpa penurunan performance yang berarti. Selain itu databasenya sangat kuat sehingga tidak akan rusak sekalipun listrik untuk server mati mendadak (danzoo46)

\section{Bahasa}

Myob v.17 merupakan software buatan Australia, hanya bisa menampilkan tampilan bahasa Inggris. Software tersebut dibuat oleh Data-Tech Software Pty. Ltd. Australia. Data-Tech Sofware merekomendasikan Myob accounting, arsitek, konsultan, galeri seni, salon kecantikan kontraktor dan menyediakan daftar rekening siap pakai. Untuk menampilkan bahasa lain diperlukan "onscreen translation program" atau program penerjemah on-screen (yang terdapat di layar) atau mungkin add-on lain yang harus ditambah sendiri.

Accurate v.4 merupakan software yang diciptakan putra putri Bangsa Indonesia yang berdiri dibawah bendera PT. Cipta Piranti Sejahtera lebih dikenal dengan sebutan CPSSoft yang berlokasi di Jakarta. Mampu menampilkan dua jenis bahasa untuk tampilannya yaitu Bahasa Indonesia dan Bahasa Inggris. Sehingga lebih familiar dan mudah dipahami di Indonesia.

Myob merupakan software buatan luar negeri yang lebih tepatnya perusahaan dari Australia sehingga mungkin kurang bisa memenuhi permintaan pasar di Indonesia bila dibandingkan Accurate.

\section{Fitur-fitur}

Pada Myob metode persediaan dengan menggunakan average, belum ada multi warehouse sehingga mengakibatkan pengelolaan atas barang konsinyasi relatif sulit dikelola dalam Myob, tidak ada fitur untuk mengelola perusahaan dengan multi company artinya laporan konsolidasi tidak dapat diharapkan dapat dibuat dengan menggunakan Myob.

Untuk Accurate terdapat fitur penting seperti mencatat transaksi dalam berbagai mata uang (multi currency) dengan kurs komersil serta kurs pajak, multi sales tax, multi user, multi company, multi level discount, multi unit dengan 3 level unit, metode persediaan dengan FIFO serta Average, multi warehouse, dan dapat mengonsolidasikan laporan keuangan dari beberapa anak perusahaan.

\section{Perpajakan}

Pada Myob belum ada feature perpajakan di dalamnya karena Myob merupakan software buatan luar negeri. Pembuatan laporan yang berkaitan dengan PPN dan lainnya harus dikelola diluar software Myob karena tidak sesuai dengan sistem perpajakan yang berlaku di Indonesia.

Untuk Accurate sudah ada feature pajak. Tax report dari PPN IN dan OUT sampai pada SPT Tahunan Form 1771 secara otomatis yang berlaku di Indonesia. Standart akuntansi yang digunakan pun sudah sesuai dengan standart akuntansi yang ada di Indonesia, terkait dengan pencatatan dan pelaporan keuangannya.

\section{Laporan Keuangan}

Mempunyai kemampuan untuk mengeksplorasi semua laporan ke program Excel tanpa melalui proses ekspor/impor file yang merepotkan. Laporan keuangan untuk Myob menampilkan laporan keuangan komparasi serta menampilkan analisis laporan dalam bentuk grafik. Disamping itu kemampuan trash back semua laporan ke semua dokumen dan sumber transaksi. Serta dapat diaplikasikan untuk 105 jenis perusahaan yang telah direkomendasikan. 
Laporan pada Accurate dapat mengkonsolidasikan laporan keuangan dari beberapa anak perusahaan, disamping itu dapat di view langsung dengan Microsoft excel, serta terdapat fasilitas untuk proses export dan import data. Laporan serta faktur yang dapat di customize oleh user apabila user memahami proses report dengan fast report. Sementara itu dilengkapi dengan tampilan grafis (graphics user interface) yang mudah dipahami bahkan untuk orang yang baru pertama kali menggunakannya (Rahmat $\mathrm{H}$. 2010).

\section{Digit Akun dan Nilai Transaksi}

Digit akun pada Myob mencapai lima (5) digit sedangkan pada Accurate digit akunnya mencapai 30 digit. Nilai transaksi yang dapat di cover Myob accounting software mencapai 11 digit sedangkan untuk Accurate accounting software bisa mencapai 15 digit dan dua desimal atau setara dengan 920 triliun.

\subsection{Komparasi Waktu Myob v.17 dan Accurate v.4}

\section{A. MYOB}

\section{Pembelian Tunai}

Proses penyelesaian transaksi pembelian tunai diawali dengan input, proses, dan output. Untuk input pembelian tunai dimulai dari proses melakukan entry data barang melalui inventory > item list dan melakukan entry data supplier melalui card file. Sedangkan proses pembelian tunai dimulai dengan melakukan entry purchases di fasilitas purchases. Purchases yang digunakan adalah enter purchases dengan status close bill. Dan nilai pembayaran diberikan penuh dan di entry pada paid to day dengan termin COD (cash on delivery). Untuk output pembelian tunai berupa hasil status pembelian tunai (purchases register) dan laporan pembelian tunai (purchases report).

2. Pembelian dengan uang muka/down payment

Proses penyelesaian transaksi pembelian dengan uang muka (down payment) diawali dengan input, proses, dan output. Untuk input pembelian tunai dimulai dari proses melakukan entry data barang melalui item list dan melakukan entry data supplier melalui card file. Sedangkan proses pembelian dengan uang muka (down payment) dimulai dengan melakukan enter purchases di fasilitas purchases. Purchases yang digunakan adalah enter purchases dengan status order (merupakan proses pesanan yang berisi barang-barang yang diminta untuk dibeli dan jumlah kuantitas yang akan dibeli, syarat pembayaran (term), harga beli yang telah melalui kesepakatan dengan pemasok, biaya angkut dan down payment (uang muka) untuk mencatat nilai uang muka yang diberikan atas pesanan pembelian produk pada transaksi tersebut melalui paid to day. Setelah itu pilih pay bills (merupakan pembayaran hutang ke pemasok yang akan mengakhiri siklus pembelian order). Untuk output pembelian dengan uang muka berupa hasil status pembelian dengan uang muka (purchases register) dan laporan pembelian dengan uang muka (purchases report).

3. Pembelian kredit

Proses penyelesaian transaksi pembelian kredit diawali dengan input, proses, dan output. Untuk input pembelian tunai dimulai dari proses melakukan entry data barang melalui item list dan melakukan entry data supplier melalui card file. Sedangkan proses pembelian tunai dimulai dengan melakukan entry purchases di fasilitas purchases. Purchases yang digunakan adalah enter purchases dengan status bill dan purchases payment (merupakan pembayaran hutang ke pemasok yang akan mengakhiri siklus pembelian). Perbedaan untuk langkah pembelian dengan uang muka dan kredit terletak pada barang yang sudah diterima atau belum dan jumlah pembayaran yang diberikan pada 
purchases payment. Apabila pembelian dengan uang muka maka barang masih belum diterima karena masih order dan pembayaran dilakukan berdasarkan nilai uang muka yang diberikan sedangkan pembelian dengan kredit terletak pada barang yang sudah diterima dan pembayaran dilakukan dengan cara mengangsur (kredit) yang menggunakan termin. Untuk output pembelian tunai berupa hasil status pembelian kredit (purchases register) dan laporan pembelian kredit (purchases report).

B. Accurate

1. Pembelian Tunai

Proses penyelesaian transaksi pembelian tunai diawali dengan input, proses dan output. Untuk input pembelian tunai dimulai dari proses melakukan entry data barang melalui item list dan melakukan entry data supplier melalui card file. Sedangkan proses pembelian tunai dimulai dengan melakukan entry purchases di fasilitas purchases. Purchases yang digunakan adalah purchases invoice (merupakan proses penagihan dari pihak pemasok ke perusahaan) dan purchases payment (merupakan pembayaran hutang ke pemasok yang akan mengakhiri siklus pembelian). Untuk output pembelian tunai berupa hasil status pembelian tunai (purchases register) dan laporan pembelian tunai (purchases report).

2. Pembelian dengan Uang muka (down payment)

Proses penyelesaian transaksi pembelian dengan uang muka (down payment) diawali dengan input, proses dan output. Untuk input pembelian tunai dimulai dari proses melakukan entry data barang melalui item list dan melakukan entry data supplier melalui card file. Sedangkan proses pembelian dengan uang muka (down payment) dimulai dengan melakukan entry purchases di fasilitas purchases. Purchases yang digunakan adalah purchases order (merupakan proses pesanan yang berisi barang-barang yang diminta untuk dibeli dan jumlah kuantitas yang akan dibeli, syarat pembayaran, harga beli yang telah melalui kesepakatan dengan pemasok, biaya angkut) dan down payment (uang muka) unuk mencatat nilai uang mukan yang diberikan atas pesanan pembelian produk pada transaksi tersebut. Setelah itu pilih purchases payment (merupakan pembayaran hutang ke pemasok yang akan mengakhiri siklus pembelian). Untuk output pembelian dengan uang muka berupa hasil status pembelian dapat dilihat dan laporan pembelian dengan uang muka (purchases report).

3. Pembelian Kredit

Proses penyelesaian transaksi pembelian kredit diawali dengan input, proses dan output. Untuk input pembelian tunai dimulai dari proses melakukan entry data barang melalui item list dan melakukan entry data supplier melalui card file. Sedangkan proses pembelian tunai dimulai dengan melakukan entry purchases di fasilitas purchases. Purchases yang digunakan adalah purchases invoice (merupakan proses penagihan dari pihak pemasok ke perusahaan) dan purchases payment (merupakan pembayaran hutang ke pemasok yang akan mengakhiri siklus pembelian). Perbedaan untuk langkah pembelian secara tunai dan kredit terletak pada barang yang sudah diterima atau belum dan jumlah pembayaran yang diberikan pada purchases payment. Apabila pembelian dengan uang muka maka barang masih belum diterima karena masih order dan pembayaran dilakukan berdasarkan nilai uang muka yang diberikan sedangkan pembelian dengan kredit terletak pada barang yang sudah diterima dan pembayaran dilakukan dengan cara mencicil (kredit) yang menggunakan termin (term). Untuk output pembelian tunai berupa hasil status pembelian kredit (purchases 
register) dan laporan pembelian kredit (purchases report).

\begin{tabular}{|c|c|c|c|c|}
\hline MYOB & $\begin{array}{l}\text { Waktu } \\
\text { Jakput }\end{array}$ & $\begin{array}{l}\text { Waktu } \\
\text { Proseses }\end{array}$ & $\begin{array}{l}\text { Waktu } \\
\text { Output }\end{array}$ & $\begin{array}{l}\text { Waktu } \\
\text { Proses }\end{array}$ \\
\hline \begin{tabular}{|l} 
Pembelian tunai \\
\end{tabular} & & 1 menit 10 detik & 39 deut & $\begin{array}{l}\text { Proses siPO } \\
\text { 3 menit } 39 \text { detik }\end{array}$ \\
\hline \begin{tabular}{|l} 
Pembelian DP \\
Pemblian kredit
\end{tabular} & 1 menit 50 detik & 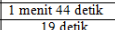 & $\begin{array}{l}40 \text { detik } \\
3 \text { detiti }\end{array}$ & $\begin{array}{l}4 \text { menit } 23 \text { detik } \\
2 \text { menin } 8 \text { detikit }\end{array}$ \\
\hline & & & & \\
\hline ACCURATE & $\begin{array}{l}\text { Walktu } \\
\text { Input }\end{array}$ & $\begin{array}{l}\text { Waltu } \\
\text { Proses }\end{array}$ & $\begin{array}{l}\text { Waktu } \\
\text { Outumt }\end{array}$ & $\begin{array}{c}\text { Waktu } \\
\text { Proses POO }\end{array}$ \\
\hline Pembeli & 1 menit & nit, 40 detik & 16 & $2 \mathrm{mnt}, 56 \mathrm{dtk}$ \\
\hline & & & & $4 \mathrm{mnt}, 31 \mathrm{dtk}$ \\
\hline Pembelian kredit & $1 \frac{1 \text { mentit }}{1 \text { menit }}$ & \begin{tabular}{|l} 
ment, 1 denk \\
1 menit. 5 detik
\end{tabular} & $\begin{array}{l}10 \text { dentik } \\
\end{array}$ & $\frac{2 \mathrm{mnnt}, 3 \mathrm{datk}}{2 \mathrm{mnt}, 21 \mathrm{dtk}}$ \\
\hline
\end{tabular}

3.3. Komparasi Waktu penyelesaian langkah proses penjualan Myob v.17 dan Accurate v.4

A. MYOB

1. Penjualan Tunai

Proses penyelesaian transaksi penjualan tunai diawali dengan input, proses dan output. Untuk input penjualan tunai dimulai dari proses melakukan entry data barang melalui inventory > item list dan melakukan entry data customer melalui card file. Sedangkan proses penjualan tunai dimulai dengan melakukan entry sales di fasilitas sales. Sales yang digunakan adalah enter sales dengan status close invoice. Dan nilai penerimaan uang diberikan penuh dan di entry pada paid to day dengan termin COD (cash on delivery). Untuk output penjualan tunai berupa hasil status penjualan tunai (sales register) dan laporan penjualan tunai (sales report).

2. Penjualan dengan uang muka/down payment

Proses penyelesaian transaksi penjualan dengan uang muka (down payment) diawali dengan input, proses dan output. Untuk input penjualan tunai dimulai dari proses melakukan entry data barang melalui item list dan melakukan entry data customer melalui card file. Sedangkan proses penjualan dengan uang muka (down payment) dimulai dengan melakukan enter sales di fasilitas sales. Sales yang digunakan adalah enter sales dengan status order (merupakan proses pesanan yang berisi barang-barang yang diminta untuk dijual dan jumlah kuantitas yang akan dijual, syarat pembayaran (term), harga jual yang telah melalui kesepakatan dengan pelanggan, biaya angkut dan down payment (uang muka) untuk mencatat nilai uang muka yang diberikan atas pesanan penjualan produk pada transaksi tersebut melalui paid to day. Setelah itu pilih receive payment (merupakan penerimaan piutang ke customer yang akan mengakhiri siklus penjualan order). Untuk output penjualan dengan uang muka berupa hasil status penjualan dengan uang muka (purchases register) dan laporan penjualan dengan uang muka (sales report).

3. Penjualan kredit

Proses penyelesaian transaksi penjualan kredit diawali dengan input, proses dan output. Untuk input penjualan tunai dimulai dari proses melakukan entry data barang melalui item list dan melakukan entry data customer melalui card file. Sedangkan proses pembelian tunai dimulai dengan melakukan entry sales di fasilitas sales. Sales yang digunakan adalah enter sales dengan status invoice dan receive payment (merupakan penerimaan piutang ke pelanggan yang akan mengakhiri siklus penjualan). Perbedaan untuk langkah penjualan dengan uang muka dan kredit terletak pada barang yang sudah dikirim atau belum dan jumlah penerimaan piutang yang diberikan pada receive payment. Apabila penjualan dengan uang muka maka barang masih belum diterima karena masih order dan penerimaan piutang dilakukan berdasarkan nilai uang muka yang diberikan sedangkan penjualan dengan kredit terletak pada barang yang sudah dikirim dan penerimaan piutang dilakukan dengan cara mengangsur (kredit) yang menggunakan termin. Untuk output penjualan tunai berupa hasil status penjualan kredit (sales register) dan laporan penjualan kredit (sales report). 
B. Accurate

1. Penjualan Tunai

Proses penyelesaian transaksi penjualan tunai diawali dengan input, proses, dan output. Untuk input penjualan tunai dimulai dari proses melakukan entry data barang melalui item list dan melakukan entry data customer melalui card file. Sedangkan proses penjualan tunai dimulai dengan melakukan entry sales di fasilitas sales. Sales yang digunakan adalah sales invoice (merupakan proses penagihan dari pihak customer ke perusahaan) dan sales receipt (merupakan penerimaan piutang dari pelanggan yang akan mengakhiri siklus penjualan). Untuk output penjualan tunai berupa hasil status penjualan tunai (sales register) dan laporan penjualan tunai (sales report).

2. Penjualan dengan Uang muka (down payment)

Proses penyelesaian transaksi penjualan dengan uang muka (down payment) diawali dengan input, proses, dan output. Untuk input penjualan tunai dimulai dari proses melakukan entry data barang melalui item list dan melakukan entry data supplier melalui card file. Sedangkan proses pembelian dengan uang muka (down payment) dimulai dengan melakukan entry purchases di fasilitas purchases. Purchases yang digunakan adalah purchases order (merupakan proses pesanan yang berisi barang-barang yang diminta untuk dibeli dan jumlah kuantitas yang akan dibeli, syarat pembayaran, harga beli yang telah melalui kesepakatan dengan pemasok, biaya angkut) dan down payment (uang muka) unuk mencatat nilai uang muka yang diberikan atas pesanan pembelian produk pada transaksi tersebut. Setelah itu pilih purchases payment (merupakan pembayaran hutang ke pemasok yang akan mengakhiri siklus pembelian). Untuk output pembelian dengan uang muka berupa hasil status pembelian dapat dilihat dan laporan pembelian dengan uang muka (purchases report).

3. Penjualan Kredit

Proses penyelesaian transaksi pembelian kredit diawali dengan input, proses dan output. Untuk input pembelian tunai dimulai dari proses melakukan entry data barang melalui item list dan melakukan entry data supplier melalui card file. Sedangkan proses pembelian tunai dimulai dengan melakukan entry purchases di fasilitas purchases. Purchases yang digunakan adalah purchases invoice (merupakan proses penagihan dari pihak pemasok ke perusahaan) dan purchases payment (merupakan pembayaran hutang ke pemasok yang akan mengakhiri siklus pembelian). Perbedaan untuk langkah pembelian secara tunai dan kredit terletak pada barang yang sudah diterima atau belum dan jumlah pembayaran yang diberikan pada purchases payment. Apabila pembelian dengan uang muka maka barang masih belum diterima karena masih order dan pembayaran dilakukan berdasarkan nilai uang muka yang diberikan sedangkan pembelian dengan kredit terletak pada barang yang sudah diterima dan pembayaran dilakukan dengan cara mencicil (kredit) yang menggunakan termin (term). Untuk output pembelian tunai berupa hasil status pembelian kredit (purchases register) dan laporan pembelian kredit (purchases report).

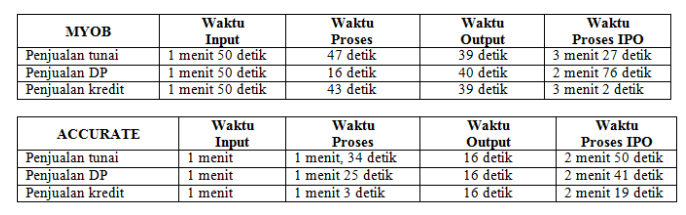

\section{KESIMPULAN}

Melakukan komparasi antara Myob dan Accurate untuk membandingkan perangkat lunak buatan lokal (dalam negeri) dan luar negeri. Dengan harapan 
user akan memperoleh gambaran kecocokan software akuntansi yang tersedia apabila akan diterapkan dan diimplementasikan untuk membantu pengelolaan bisnis. Pemakaian perangkat lunak dipilih sesuai dengan visi pengguna yang bersifat masa depan untuk kemudian dijabarkan strateginya sesuai dengan visi pengguna. Disamping itu pemilihan perangkat lunak juga didasarkan pada pembenahan sistem dan pengembangan sumber daya manusianya.

Dengan adanya penelitian ini maka akan didapat suatu output yang bisa menjadi acuan bagi para pengguna atau pemakai atau user perangkat lunak aplikasi akuntansi dalam mengaplikasikan Myob dan Accurate sesuai dengan kebutuhan pasar. Dalam hal ini adalah pasar Myob dan Accurate.

Berdasarkan permasalahan dan pembahasan di atas maka dapat disimpulkan :

1. Gambaran umum untuk Myob sebagai perangkat lunak akuntansi buatan Australia berbeda dengan Accurate Accounting Software buatan Indonesia. Gambaran yang dimaksudkan adalah tampilan awal, setup database, bahasa, fitur-fitur, perpajakan, laporan keuangan, digit akun dan nilai transaksi. Dari segi tampilan awal (display), untuk Myob terlihat formal dengan 5 icon. Untuk Accurate memiliki 6 gambar icon, dengan display lebih modern. Dari segi setup database, untuk Myob menggunakan database Myob merupakan database yang dikunci, artinya pengguna tidak dapat melakukan modifikasi laporan, modifikasi field di Myob sehingga customization sulit untuk dipenuhi. Untuk Accurate Menggunakan database server firebird, database SQL dari kelas Client/server. Accurate mampu melayani sampai ratusan user sekaligus tanpa penurunan performance yang berarti job costing software Selain itu database-nya sangat kuat sehingga tidak akan rusak sekalipun listrik untuk server mati mendadak. Dari segi bahasa, untuk Myob menampilkan tampilan bahasa Inggris dan untuk Accurate menampilkan dua jenis bahasa untuk tampilannya yaitu Bahasa Indonesia dan Bahasa Inggris. Dari segi fitur, untuk Myob metode persediaan dengan menggunakan average, belum ada multi warehouse sehingga mengakibatkan pengelolaan atas barang konsinyasi relatif sulit dikelola dalam Myob, tidak ada fitur untuk mengelola perusahaan dengan multi company artinya laporan konsolidasi tidak dapat diharapkan dapat dibuat dengan menggunakan Myob. Untuk Accurate, mencatat transaksi dalam berbagai mata uang (multi currency) dengan kurs komersil serta kurs pajak, multi sales tax, multi user, multi company, multi level discount, multi unit dengan 3 level unit, metode persediaan dengan FIFO serta Average, multi warehouse, dan dapat mengonsolidasikan laporan keuangan dari beberapa anak perusahaan. Dari segi perpajakan, untuk Myob belum ada feature perpajakan di dalamnya karena Myob merupakan software buatan luar negeri sehingga tidak ada fitur perpajakan didalamnya. Untuk Accurate, sudah ada feature pajak. Tax report dari PPN IN dan OUT sampai pada SPT Tahunan Form 1771 secara otomatis yang berlaku di Indonesia. Dari segi laporan keuangan, untuk Myob menampilkan laporan keuangan komparasi serta menampilkan analisis laporan dalam bentuk grafik. Disamping itu kemampuan trash back semua laporan ke semua dokumen dan sumber transaksi. Serta dapat diaplikasikan untuk 105 jenis perusahaan yang telah direkomendasikan. Untuk Accurate, dapat mengkonsolidasikan laporan keuangan dari beberapa anak perusahaan, disamping itu dapat di view langsung dengan Microsoft excel, serta terdapat fasilitas untuk proses export dan import data. Laporan serta faktur yang dapat di customize oleh user 
apabila user memahami proses report dengan fast report. Dari segi digit akun dan nilai transaksi, untuk Myob mencapai lima (5) digit sedangkan pada Accurate digit akunnya mencapai 30 digit. Untuk Accurate, mencapai 15 digit dan dua desimal atau setara dengan 920 triliun.

2. Lama waktu yang dipergunakan dalam penyelesaian langkah proses pembelian (pembelian tunai, pembelian dengan uang muka/down payment, pembelian kredit) dengan menggunakan Myob v.17 adalah untuk proses IPO pembelian tunai 3 menit 39 detik, proses IPO pembelian down payment 4 menit 23 detik, dan untuk proses IPO pembelian kredit 2 menit 8 detik.

Lama waktu yang dipergunakan dalam penyelesaian langkah proses pembelian (pembelian tunai, pembelian dengan uang muka/down payment, pembelian kredit) dengan menggunakan Accurate v.4 adalah untuk proses IPO pembelian tunai 2 menit 56 detik, proses IPO pembelian down payment 4 menit 31 detik, dan untuk proses IPO pembelian kredit 2 menit 21 detik.

3. Lama waktu yang dipergunakan dalam penyelesaian langkah proses penjualan (penjualan tunai, penjualan dengan uang muka/down payment, penjualan kredit) dengan menggunakan Myob v.17 adalah untuk proses IPO penjualan tunai 3 menit 27 detik, proses IPO penjualan down payment 2 menit 76 detik, dan untuk proses IPO penjualan kredit 3 menit 2 detik.

Lama waktu yang dipergunakan dalam penyelesaian langkah proses penjualan (penjualan tunai, penjualan dengan uang muka/down payment, penjualan kredit) dengan menggunakan Accurate v.4 adalah untuk proses IPO penjualan tunai 2 menit 50 detik, proses IPO penjualan down payment 2 menit 41 detik, dan untuk proses IPO penjualan kredit 2 menit 19 detik.

\section{DAFTAR PUSTAKA}

1. Khakim, K.N. 2011, Analisis FaktorFaktor Yang Mempengaruhi Penerimaan Dan Penggunaan Software Akuntansi Myob Dengan Menggunakan Pendekatan Technology Acceptance Model (Tam), Semarang : Skripsi, Fakultas Ekonomi Universitas Diponegoro

2. Sastrawan U.,Sp, Ratih Pratiwi,Se dan Eka Merdekawati, Se. 2012, Perbandingan Penerapan Sistem Akuntansi Konvensional Dengan Sistem Akuntansi Berbasis Komputer Pada Perusahaan Dagang, 08 Jurnal Sains Terapan Edisi II Vol-2 (1) :114130

3. Wan Maimunah Binti Wan Ishak. 2002, Kemahiran menggunakan perisian prakauan dan pemrosesan perkataan (word processing) di kalangan peljar diploma perakauan : satu tinjauan di lima politeknik di Malaysia Kolej Universiti Teknologi Tun Hussei Onn

4. Istianingsih,Dr. dan Wiwik Utami, SE, Msi, Ak. Pengaruh Kepuasan Pengguna Sistem Informasi Terhadap Kinerja Individu (Studi Empiris Pada Pengguna Paket Program Aplikasi Sistem Informasi Akuntansi Di Indonesia), Fakultas Ekonomi Universitas Mercubuana

5. Prakoso G. 2010, Analisis Pengaruh Pengetahuan Akuntansi, Pengetahuan Teknologi Informasi dan Kemampuan Berbahasa Inggris Terhadap Penguasaan SAP Pada Mahasiswa Strata Satu Jurusan Akuntansi Stie Perbanas Surabaya : Sekolah Tinggi Ilmu Ekonomi Perbanas, Surabaya

6. Yulius Kurnia S. 2005. Pengaruh Pengetahuan Teknologi Informasi yang Dikuasai Akuntan Pendidik, Persepsi Manfaat Sistem Informasi dan Kecocokan Antara Tugas Teknologi Terhadap Pemanfaatan Kinerja Teknologi Informasi Oleh Akuntan Pendidik.Jurnal Kajian 
Bisnis, vol. 13, no.2, mei 2005,194205

7. Erma Suryani. 2009.Pengaruh pengetahuan akuntansi dan pemanfaatan software Akuntansi terhadap kinerja individu mahasiswa jurusan akuntansi STIE Perbanas Surabaya. Skripsi Sarjana Perbanas : STIE Perbanas Surabaya. 